\title{
BONE MARROW DEPRESSION AFTER DRUG THERAPY IN PATIENTS WITH SYSTEMIC LUPUS ERYTHEMATOSUS
}

\author{
BY \\ FREDERIC C. MCDUFFIE* \\ From the Departments of Medicine and Microbiology, University of Mississippi Medical Center, \\ Jackson, Mississippi
}

Since the first report of the lupus-like syndrome occurring after hydralazine administration (Kaufman, 1953) there has been a great deal of interest in the problem whether such reactions and similar ones to other drugs represent self-limiting allergic responses or are drug-induced exacerbations of disseminated lupus itself in patients with a lupus diathesis (Holley, 1961). Because some patients who have had such reactions later go on to develop typical lupus, and because a few such patients who have died have exhibited typical lesions of lupus post mortem (Benton, Tynes, Register, Alford, and Holley, 1962), it seems likely that the latter view is more likely to be correct. However, in addition to the fact that certain drugs may cause generalized exacerbations of this disease, it has been observed that patients with disseminated lupus appear to be prone to develop true allergic reactions to drugs and other chemicals. Recently we have seen three such patients develop severe bone marrow depression after therapy with drugs not commonly associated with blood dyscrasias. The possibility of such a complication occurring in such peculiarly susceptible individuals deserves emphasis.

\section{Case Reports}

Case 1, a 13-year-old white girl, was first admitted to hospital in November, 1959, with a 10-month history of polyarthritis and skin eruption. At that time swelling of the distal interphalangeal joint of one thumb was noted, the L.E.-cell test was positive, and the serum gamma globulin level was $3 \cdot 3 \mathrm{~g}$. per cent. She was thought to have mild systemic lupus erythematosus and was given hydroxychloroquine, $200 \mathrm{mg}$. daily. On this drug alone she had virtually no symptoms until June, 1960 , when she abruptly developed severe weakness, fever, nausea, and epistaxis.

Examination.-She had a temperature of $100^{\circ} \mathrm{F}$., was very pale, and had flame-shaped haemorrhages in the fundi and a palpable spleen.

\footnotetext{
* Present address: Mayo Clinic, Rochester, Minnesota.
}

Haematocrit $17, \mathrm{Hb} 5 \cdot 3 \mathrm{~g}$. per cent., platelets $29,000 /$ mm. ${ }^{3}$, W.B.C. $400 / \mathrm{mm}^{3}{ }^{3}(120$ monocytes, 80 lymphocytes, 20 eosinophils, 180 polymorphs); direct Coombs test negative; serum gamma globulin $3 \cdot 7 \mathrm{~g}$. per cent.

Bone marrow biopsy showed only fibrous tissue, and no recognizable bone marrow elements were present.

Treatment.-Hydroxychloroquine was immediately discontinued, and the patient was given prednisolone, penicillin, and streptomycin, and was kept in isolation. Her recovery was rapid so that she was able to be discharged in 3 weeks' time.

Follow-up.-A repeat bone marrow test in October, 1960 , was normal, and the spleen was no longer palpable. She has not received any therapy since November, 1960. L.E.-cell tests are now negative, and the serum gamma globulin was $2 \cdot 1 \mathrm{~g}$. per cent. in August, 1963.

Case 2, a 40-year-old white housewife, was admitted to hospital in October, 1961, with a 3-year history of aching in her back for which she had received numerous drugs. She had developed skin eruptions from codeine, sulphonamides, chloramphenicol, mandelamine, and salicylates. In August, 1961, she was given dextropropoxyphene and from then until October she took no other drugs except an unknown white tablet for a few days in September and an unknown injection October 1 . On October 3, she was seen by a physician because of generalized furunculosis and was admitted to another hospital whence she was referred to this hospital on October 8, 1961.

Examination.-She had a temperature of $101^{\circ} \mathrm{F}$. The skin was covered with numerous erythematous warm furuncles, there was some injection of the pharynx, and bilateral cervical adenopathy was present.

Haematocrit 43 , platelets $138,000 / \mathrm{mm}^{3}$, W.B.C. $800 /$ $\mathrm{mm} .{ }^{3}$ (32 monocytes, 768 lymphocytes).

Culture of a furuncle yielded Staphylococcus aureus. Bone marrow examination showed the myeloid precursors to be virtually absent, but other elements were normal. Leucocyte agglutinins were detected in the serum employing dextropropoxyphene as an antigen, while several other drugs which she had taken gave negative results.

Treatment.- She was given antibiotics and prednisolone and made a rapid recovery. 
Progress.-She was readmitted in July, 1962, with an acute polyarthritis, and at that time an L.E.-cell test was positive. W.B.C. $4,700 / \mathrm{mm}^{3}$; gamma globulin $2 \cdot 3 \mathrm{~g}$. per cent.; latex-fixation test positive $1: 320$.

Follow-up.-She has been treated with chloroquine and aspirin since that time, and her disease has not progressed. Although no evidence of renal disease was present, an unsuccessful attempt at renal biopsy was made in December, 1963.

Case 3, a 14-year-old Negro girl, was admitted to hospital in October, 1963, with a 2-month history of butterfly rash on the face, fever, and proteinuria.

Examination.-Temperature $103^{\circ} \mathrm{F}$, blood pressure $100 / 90$. There was an erythematous eruption on the face and nose, a cytoid body in the right fundus, and bilateral ankle clonus.

Haematocrit 30, W.B.C. $2,500 / \mathrm{mm}^{3}$ (300 lymphocytes, 1,700 polymorphs, 500 bands), platelets 143,000 , gamma globulin $3.3 \mathrm{~g}$. per cent., creatinine $4.2 \mathrm{mg}$. per cent. (later fell to $0.5 \mathrm{mg}$. per cent.), serum complement 9 50 per cent. units per ml. (normal 22 to 54 ).

Urine analysis revealed proteinuria ( $4 \mathrm{~g}$. per day) and a sediment containing five to ten red cells and five to ten white cells per high-power field, but no casts.

L.E.-cell tests were repeatedly negative.

Treatment.-She was thought to have disseminated lupus and was treated initially with prednisolone $60 \mathrm{mg}$. daily. This dose had to be increased to $120 \mathrm{mg}$. daily after she developed confusion and lapsed into coma.

Progress.-Upon her recovery from this attack of cerebritis, a renal biopsy showed basement membrane thickening of the glomeruli characteristic of lupus nephritis. Because of an $E$. coli present in the urine, she was begun on nitrofurantoin $400 \mathrm{mg}$. a day and was discharged on this drug plus prednisolone $60 \mathrm{mg}$. daily.

Terminal Illness. -2 weeks later she was readmitted with a 2-day history of watery diarrhoea, dyspnoea, cough, and pain in the left chest. She was critically ill and in severe respiratory distress with a temperature of $106^{\circ}$, pulse 180 , respirations 64 , and absent blood pressure. Crackling râles were heard over the left lower chest and she made only incoherent, moaning sounds in response to questions.

Haematocrit 22, platelets $104,000 / \mathrm{mm}^{3}{ }^{3}$, W.B.C. $1,000 /$ mm. $^{3}$ (140 monocytes, 860 lymphocytes), B.U.N. $73 \mathrm{mg}$. per cent. Urine analysis showed $3+$ proteinuria, five to ten white cells and a few granular casts in the sediment. Blood cultures grew Proteus, Pseudomonas, and E. coli. $X$ ray revealed a homogenous opacity throughout the left lung field and a small infiltrate in the right lung. In spite of vigorous supportive measures, glucocorticoids, and antibiotics she died 5 hours after admission.

Post mortem Examination (by Dr. H. Shahriaree*).There was severe haemorrhage and oedema of the lungs. The alveolar ducts were filled by a pink hyaline-like

* Department of Pathology, University of Mississippi Medical Center. material containing only rare inflammatory cells, characteristic of an agranulocytic pneumonia. Numerous small ulcerations of the stomach and small bowel were observed which also showed very few inflammatory cells on microscopic examination. The spleen was enlarged and there was some thickening of the walls of the vessels. The kidneys showed thickening of the basement membrane, deposition of fibrinoid, and lobulation and segmentation of the glomeruli. Microscopic examination of the bone marrow showed all elements to be normal except for an absence of mature neutrophils; this was interpreted as being consistent with an arrest of the myeloid series.

\section{Discussion}

None of the three drugs implicated in the production of agranulocytosis in these patients (and of aplastic anaemia in one) has a record of producing significant bone marrow depression. The 4-aminoquinolones have been widely used since 1946 for the treatment of and suppression of malaria but in much smaller doses than those used in the treatment of lupus and rheumatoid arthritis. Mild leucopenia has been occasionally observed (Bagnall, 1957; Winkelmann and Merwin, 1961). It is of interest that, of three fatal agranulocytic reactions caused by amodiaquin, two occurred in patients with lupus (Yates, Leeper, and Fishler, 1955; Kersley and Palin, 1959; Perry, Bartholomew, and Hanlon, 1962). Chloroquine given to patients with rheumatoid arthritis has produced one known case of fatal agranulocytosis (Kersley and Palin, 1959), one of aplastic anaemia with recovery (Wilputte, 1959), and one of thrombocytopenia (Meyler, 1959). The most common toxic reactions to chloroquine and hydroxychloroquine are deposition of the drugs in the cornea, retinopathy, depigmentation of scalp hair, nausea, and dermatitis (Drew, 1962). Dextropropoxyphene, a widely-used analgesic, has not yet been implicated as a cause of agranulocytosis, and reports of its toxicity have so far been limited to acute episodes of coma and convulsions following the ingestion of single large doses (Cann and Verhulst, 1960). Nitrofurantoin may produce a haemolytic anaemia in persons with a deficiency of the enzyme 6-glucose phosphate dehydrogenase in their red cells (Kimbro, Sachs, and Torbert, 1957). Its most important toxic effects are a symmetrical peripheral neuritis (Ellis, 1962) and an eosinophilic pneumonia (Israel and Diamond, 1962). One possible example of thrombocytopenic purpura (Chamberlin, 1963) and one of megaloblastic anaemia (Bass, 1963) due to this drug have been described.

Erslev and Wintrobe (1962), from the 7-year experience of the American Medical Association 
registry of drug-associated blood dyscrasias, compiled a list of 54 compounds believed to be potentially toxic to the bone marrow. Nitrofurantoin was included only as a potential cause of haemolytic anaemia in those with G-6-PD deficient red cells. The 4-aminoquinolones and dextropropoxyphene were not included in the list. It would seem, therefore, that in our cases the nature of the patient was more important than the nature of the drug. It is possible that the reactions observed were not actually drug-induced but were simply acute manifestations of disseminated lupus. Although leucopenia is common in lupus it usually represents a depression of the lymphocyte count rather than of the neutrophil count. In none of our patients were the severe reactions accompanied by other manifestations of acute lupus, such as rash, polyarthritis, or exacerbation of nephritis. In the two patients who survived, the subsequent course of the disease has been benign since the drugs were discontinued. The third patient developed agranulocytosis while taking a large dose of prednisolone $(60 \mathrm{mg}$. a day). Although Rokseth (1960) has reported a case of aplastic anaemia due to prednisolone, his patient had previously received $x$-irradiation for spondylitis, and the cause-and-effect relationship of the corticoid and the bone marrow depression seems doubtful. The mechanism by which bone marrow depression occurred in our patients is not clear. It is tempting to implicate an immunological mechanism in view of the many unusual antibodies that have been demonstrated in the sera of patients with lupus. Miescher (1957) has clearly distinguished between two classes of antibodies that react with white cells in the disease. One comprises the antinuclear antibodies of which the L.E. factor is one, and the other comprises antibodies reacting with cytoplasmic constituents. It is not yet clear, however, what the role of these latter antibodies may be, since they may exist in the absence of significant neutropenia. The best evidence for the existence of antibodies which actually destroy white cells or depress the bone marrow in lupus comes from such observations as that of an infant in utero developing the same severe neutropenia as its mother (Seip, 1960). Although it might be expected that such antibodies, by causing lysis of white cells, perhaps following fixation of complement, would be associated with a vigorous marrow response comparable to that present in Coombs-positive acquired haemolytic anaemia, Dausset, Colombani, and Colombani (1961) have observed that positive tests for antileucocyte antibodies in lupus are usually associated with depression of the myeloid series in the bone marrow. If in our patients drugs were involved as suspected, a more likely mechanism would be one comparable to that demonstrated in Pyramidon agranulocytosis by Moeschlin and Wagner (1952).

These workers observed in vitro agglutination of white cells by serum from a Pyramidon-sensitive patient in the presence of the drug but not in its absence. Transfusion of blood from such a patient 3 hours after Pyramidon administration to a normal individual produced a striking drop in the recipient's leucocyte count. Ackroyd (1962) has demonstrated that a similar mechanism is probably present in drug-induced thrombocytopenia. However, more work still needs to be done to clarify the role of circulating antibody in drug-induced depression of the formed elements of the blood.

\section{Summary}

Three patients with disseminated lupus erythematosus are described, of whom two developed severe agranulocytosis and one developed aplastic anaemia, probably drug-induced. In each instance a drug not known to produce bone marrow depression with any significant frequency was implicated. It is postulated that patients with disseminated lupus are peculiarly likely to develop drug reactions of this kind. The mechanism is not clear, but an antibody to the drug which is in turn bound to the surface of the cell is attractive. Such reactions are probably different from the drug-precipitated lupus that has been seen after the administration of hydralazine, anticonvulsants, and other drugs.

I wish to express my appreciation to Dr. W. N. Bell for permission to include Case 2 and to Dr. C. Goetz for histological interpretations in Cases 1 and 3.

\section{REFERENCES}

Ackroyd, J. F. (1962). Proc. roy. Soc. Med., 55, 30. Bagnall, A. W. (1957). Canad. med. Ass. J., 77, 182. Bass, B. H. (1963). Lancet, 1, 530.

Benton, J. W., Tynes, B., Register, H. B., Alford, C., and Holley, H. L. (1962). J. Amer. med. Ass., 180, 115.

Cann, H. M., and Verhulst, H. L. (1960). Amer. J. Dis. Child., 99, 380.

Chamberlin, R. T. (1963). J. Maine med. Ass., 54, 54.

Dausset, J., Colombani, J., and Colombani, M. (1961). Blood, 18, 672.

Drew, J. F. (1962). Med. J. Aust., 2, 618.

Ellis, F. G. (1962). Lancet, 2, 1136.

Erslev, A. J., and Wintrobe, M. M. (1962). J. Amer. med. Ass., 181, 114.

Holley, H. L. (1961). Ann. intern. Med., 55, 1036.

Israel, H. L., and Diamond, P. (1962). New Engl. J. Med., 266, 1024. 
Kaufman, M. (1953). J. Amer. med. Ass., 151, 1488.

Kersley, G. D., and Palin, A. G. (1959). L Lancet, $2,886$.

Kimbro, E. L., Jr., Sachs, M. V., and Torbert, J. V. (1957). Bull. Johns Hopk. Hosp., 101, 245.

Meyler, L. (1959). Ned. T. Geneesk., 103, 2427.

Miescher, P. (1957). Vox Sang. (Basel), 2, 145.

Moeschlin, S., and Wagner, K. (1952). Acta haemat. (Basel), 8, 29.

Perry, H. O., Bartholomew, L. G., and Hanlon, D. G. (1962). J. Amer. med. Ass., 179, 598.

Rokseth, R. (1960). Lancet, 1, 680.

Seip, M. (1960). Arch. Dis. Childh., 35, 364.

Wilputte, J. (1959). J. belge Méd. phys. Rhum., 14, 34

Winkelmann, R. K., Merwin, C. F., and Brunsting, L. A. (1961). Ann. intern. Med., 55, 772.

Yates, J. E., Leeper, R. W., and Fishler, M. C. (1955). Kaiser Fdn med. Bull., 3, 193.

Dépression médicamenteuse de la moelle osseuse chez des malades atteints de lupus érythémateux disséminé

\section{RÉSUMÉ}

On décrit trois cas de lupus érythémateux disséminé suivis de complications d'origine probablement médicamenteuse: deux malades ont développé une sévère agranulocytose et le troisième une anémie aplastique. Dans tous les cas il s'agissait d'un médicament qui n'avait pas la réputation de déprimer la moelle osseuse avec une fréquence significative. On postule que les malades atteints de lupus érythémateux disséminé sont particulièrement enclins à développer des réactions médicamenteuses de ce genre Le mécanisme n'en est pas clair et il peut bien s'agir d'un anticorps contre le médicament s'attachant à la surface de la cellule. De telles réactions sont probablement différentes de celles ou le lupus se voit précipité après l'administration d'hydralzine, d'un anticonvulsif ou d'un autre médicament.

\section{Depresión medicamentosa de la medula ósea en} enfermos con lupus eritematoso diseminado

\section{Sumario}

Se describen tres casos de lupus eritematoso diseminado con complicaciones de origen medicamentoso probable: dos enfermos desarrollaron una agranulocitosis grave y el tercero una anemia aplástica. En todos los casos se trataba de un medicamento que no tenía la reputación de deprimir la medula ósea con frecuencia significativa. Se postula que enfermos con lupus eritematoso diseminado desempeñan una susceptibilidad particular a reacciones medicamentosas de este tipo. El mecanismo de esta ocurrencia no es muy claro; posiblemente se trata aquí de un anticuerpo antimedicamentoso ligado a la superficie de la célula. Tales reacciones son probablemente diferentes de las en que el lupus se ve precipitado después de la administración de hidralzina, de un anticonvulsivo o de otro fármaco. 